\title{
Gomisin A Inhibits Tumor Growth and Metastasis through Suppression of Angiogenesis
}

\author{
Do-Yoon Kim¹, Ho Jin Yu', Mi So Yoon', Joo Hoon Park', Sang-Hee Jang ${ }^{2}$ and Hwan Myung Lee ${ }^{1}$ * \\ ${ }^{1}$ Institute of Basic Science and Department of Cosmetic Science, Hoseo University, Asan 336-795, Korea \\ ${ }^{2}$ Department of Wellbeing Food, Gumi University, Gumi 730-711, Korea
}

Received July 26, 2012 /Revised August 3, 2012 /Accepted August 7, 2012

\begin{abstract}
Cancer chemotherapy drugs command a large share of the market, and the development of new therapeutics with high efficacy and specificity is an active area of study. Recently, the development of cancer therapeutics from natural products targeting angiogenesis has drawn attention due to conventional chemotherapeutics showing serious side effects and resistance in cancer cells. In this study, we investigated the pharmacological efficacy of Gomisin A, an active ingredient of Schizandra chinensis baillon, on tumor growth and metastasis. Administration of Gomisin A at 10 and $100 \mu \mathrm{g} / \mathrm{ml}$ reduced tumor growth in vivo by $80.5 \pm 8.1 \%$ and $96.2 \pm 2 \%$, respectively, compared with positive tumor controls. Treatment of Gomisin A in normal and various tumor cell lines did not exert significant toxicity. Mice treated with Gomisin A at a concentration of 10 and $100 \mu \mathrm{g} /$ head showed a significant reduction in tumor-induced angiogenesis of $151 \pm 16.9 \%$ and $98.5 \pm 29.5 \%$, respectively. Furthermore, tumor metastasis analysis revealed that the administration of Gomisin A at a concentration of 10 and $100 \mu \mathrm{g} / \mathrm{head}$ inhibited tumor metastasis by $13.5 \pm 8.56 \%$ and $58.3 \pm 9.12 \%$, respectively. In addition, Gomisin A significantly decreased cell adhesion of the B16BL6 cells to the extracellular matrix. These results demonstrate that Gomisin A inhibits tumor growth via suppression of angiogenesis and tumor metastasis inhibition, without cellular toxicity. The pharmacological efficacy of Gomisin A suggests that it may be a potential candidate for the development of cancer drugs.
\end{abstract}

Key words : Gomisin A, tumor growth, angiogenesis, metastasis, Schizandra chinensis

\section{서 론}

암(Cancer)은 의약품 시장 중 가장 큰 시장의 하나이며, 수 없이 많은 새로운 항암화학요법제가 연구, 개발 되고 있다. 그럼에도 불구하고 암 세포의 이질성, 다양한 발병 원인 등으 로 인해 암의 성장과 전이에 필수적인 인자를 규명하지 못함 으로써, 효과적인 예방 및 치료제의 개발이 지연되고 있다. 현재까지 적용되고 있는 암의 대표적인 치료법으로는 외과적 수술과 방사선 치료가 가장 잘 알려져 있으나, 이들은 전이 암(metastatic cancer)의 존재 시 치료의 한계를 나타내며 대부 분 초기 암의 치료에 효과를 나타내고 있다[6]. 지금까지 많은 연구자들이 항암화학요법제 개발에 몰두해 왔으나, 항암화학 요법제의 대부분은 골수기능 및 면역력의 저하, 혈소판 감소, 탈모 등의 심각한 독성뿐만 아니라 약제 내성을 나타내고 있 어 항암치료의 많은 한계를 노출시켜 왔다[13,15,21]. 이러한 기존 항암화학요법제의 문제점들을 보완하기 위해 혈관신생 억제와 같은 새로운 치료의 표적개발과 함께 항암화학요법제 의 독성을 경감시키고 약제 내성 발현을 이겨낼 수 있는 다른

*Corresponding author

Tel : +82-41-540-9551, Fax : +82-41-540-9538

E-mail : kacsital@hoseo.edu
약물과의 병용 투여 등 다양한 연구가 진행되고 있으나 큰 성과를 얻지 못하고 있다.

대부분의 solid tumor의 경우 중심부는 혈관이 형성되어 있 지 않아서 산소와 영양분의 공급을 위해 새로운 혈관의 형성이 매우 활발하게 진행되고 있다[7]. 신혈관형성(angiogenensis) 은 기존에 있던 혈관에서 새로운 모세혈관이 형성되는 과정을 말하며, 초기 발생과정, 암의 형성 및 전이 과정에서 중요한 역할을 한다[7,8,9]. 따라서 신혈관형성의 억제는 독성이 적은 항암화학요법제 신약 기반의 주요 target이 되고 있다. 그러나 대부분의 신혈관형성 억제제는 angiostatin, Maspin, Canstatin 등 endogenous regulators에 대한 많은 연구가 진행되고 있다 $[14,20,25]$. 이들은 대부분 단백질로 구성되어 있어 체내에 투 여 시 다양한 단백질 분해효소 및 결합물질 등에 의해 활성이 억제되는 한계를 안고 있다. 최근 천연물로부터 인체 독성이 적으면서 안정한 신혈관형성 억제제를 발굴하고자 노력하고 있으며, 현재까지 EGCG, Capsaicin, Catechin 등의 폴리페놀 류 물질들이 신혈관생성 억제 활성을 가지고 있다는 연구 결 과들이 보고되고 있다[17].

최근 천연물의 활용과 대체요법 등으로 암의 예방과 치료의 방향이 새롭게 전환되고 있으며, 특히 천연물을 이용한 우수 한 항암 효과를 가질 수 있는 천연물 유래의 새로운 항암화학 
요법제의 탐색에 초점이 맞추어지고 있다[1,13,23]. 특히 식물 유래 pholyphenol 성분들의 항암, 항염증, 항균, 면역조절 등 의 다양한 기능이 밝혀지면서 그 중요성이 인식되어지고 있으 며, 초기 발암 단계를 억제함으로서 항암작용 물질로 주목을 받고 있다[3,4,11,24]. 오미자(Schizandra chinensis Baillon)는 우 리나라를 비롯한 중국, 일본 등의 여러나라에서 약용식물로 사용되고 있으며, 중추신경 기능강화, 혈액순환 개선, 혈압강 하 작용, 간기능 복구효과, 항당뇨 등에 효과가 있다고 보고되 어 있다[2,12,16]. 오미자의 다양한 생리 활성을 나타내는 주요 성분은 Schizandrin, Gomisin A-H, Pregomisin 등의 lignan화 합물을 포함하는 pholyphenol 화합물인 것으로 확인되었으며 $[18,22]$, 다른 천연물에 비해 많은 pholyphenol 화합물을 함유 하고 있는것으로 알려져 있다[24]. 지금까지 오미자의 다양한 lignan화합물 및 polyphenol성분과 관련된 항암 연구는 단순 히 종양의 성장과 생존에 관한 것이 대부분이며 신혈관형성 억제를 통한 암세포의 성장과 전이에 관한 연구는 전무한 현 실이다.

본 연구는 오미자의 생리활성을 나타내는 pholyphenol계 화합물 중 하나인 Gomisin $\mathrm{A}$ 를 이용하여 in vitro 및 in vivo실 험을 통해 신혈관 형성 억제에 의한 암세포의 성장과 전이 억제 가능성을 조사하고 이를 통해 Gomisin A의 항암제로서 의 이용 가능성을 확인하고자 하였다.

\section{재료 및 방법}

\section{실험재료}

Gomisin A는 식품의약품안전청(Korea Food and Drug Administration, Korea)으로부터 분양된 표준품을 사용 하였 으며, $-80^{\circ} \mathrm{C}$ 에 보관하면서 실험에 사용하였다. 세포 및 세포주 배양에 필요한 fetal bovine serum (FBS), penicillin/streptomycin (P/S), trypsin-EDTA, Medium 199 (M199), Minimum Essential Medium (MEM), Rosewell Park Memorial Institue (RPMI) 1640 medium, Phosphate Buffered Saline (PBS)은 Hyclone (Laboratoris Inc, USA)에서 구입하였으며, basic Fibroblast Growth Factor (bFGF), Heparin은 R\&D system (USA)과 Sigma Chemical (USA)로부터 각각 구입하여 사용하 였다.

\section{세포주 및 세포 배양}

본 연구에 사용한 혈관내피세포인 human umbilical vein endothelial cell (HUVECs)은 20\% FBS, 1\% P/S, $3 \mathrm{ng} / \mathrm{ml}$ $\mathrm{bFGF}, 5 \mathrm{U} / \mathrm{ml}$ Heparin이 포함된 M199 mediums을 이용하여 배양하였다. A549 (human lung cancer cell line), Huh7 (human liver cancer cell line), Du145 (human prostate cancer cell line)는 $10 \% \mathrm{FBS}, 1 \% \mathrm{P} / \mathrm{S}$ 가 포함된 RPMI 1640 medium을 이용하여 배양하였으며, B16BL6 (mouse melanoma cell line)
는 $10 \% \mathrm{FBS}, 1 \% \mathrm{P} / \mathrm{S}$ 가 포함된 MEM medium을 이용하여 배양하였다. 배양 접시로부터 세포를 분리하기 위하여 $0.25 \%$ trypsin-EDTA 용액을 처리하였으며, 배양세포의 세척 등에는 $\mathrm{PBS}$ 를 사용하였고, 모든 세포의 배양은 $37^{\circ} \mathrm{C}, 5 \% \mathrm{CO}_{2}$ 및 $95 \%$ 이상의 습도를 유지하는 배양기에서 배양하였다.

\section{실험동물 및 사육조건}

5주령의 C57/BL6 마우스 수컷 $(20 \mathrm{~g} \pm 1 \mathrm{~g})$ 은 (주오리엔트에 서 구입하였으며, 모든 동물은 1 주일간의 순화 기간을 거친 후 실험에 사용하였다. 입수된 동물은 온도 $22 \pm 1^{\circ} \mathrm{C}$, 습도 $50 \pm 10 \%$, 조명시간 12 시간으로 제어된 환경 조건에서 사육 되었다. 동물실의 사육환경 모니터링을 위하여 자동온습도 측정기에 의하여 주기적으로 측정되었으며, 사육실에 반입 되는 멸균 소독된 물과 방사능으로 조사한 멸균된 사료로서 급수 급식하면서 사육하였다. 3-4일에 한번씩 멸균된 깔집 으로 교환하였으며, 체중계 및 실험도구 등은 알코올 소독 후 자외선 멸균 뒤 반입하여 세균에 감염되지 않도록 사육 하였다.

\section{종양 성장 억제 활성 측정}

Gomisin A의 종양성장 억제 활성 측정은 C57/BL6 마우 스에 배양된 B16BL6 melanoma cell line을 50,000 cells/50 $\mu \mathrm{l} / \mathrm{head}$ 로 피하 이식한 후 종양조직의 성장율을 대조군과 비교 분석 하였다. 시료의 처리는 3 일 간격으로 대조군 (vehicle)과 양성 대조군에는 생리 식염수를 투여하고, 실험 군에는 Gomisin A를 $10 \mu \mathrm{g} / \mathrm{head}$ 와 $100 \mu \mathrm{g} / \mathrm{head}$ 로 $100 \mu \mathrm{l}$ 씩 정맥 투여(intravenous injection) 하였다. 암 세포 이식 14 일 후 부검하여 이식된 암 조직을 절개하여 조직의 무게 를 각각 측정하여 Gomisin A의 종양 성장 억제 활성을 확 인하였다.

\section{세포 생존율(Cell viability) 측정}

HUVECs, A549, B16BL6, Du145 및 Huh7 각 세포와 세포 주를 50,000 cells $/ \mathrm{ml}$ 의 농도로 맞추고 96 well microtiter plate (Corning costar. Co)에 $100 \mu 1$ 씩 주입한 후 $37^{\circ} \mathrm{C}, 5 \%$ $\mathrm{CO}_{2}$ 배양기에서 12 시간 동안 배양하였다. Gomisin A $(0$, $0.01,0.1,1,10,100 \mu \mathrm{g} / \mathrm{ml}$ ) 농도별로 각 well 당 $100 \mu \mathrm{l}$ 씩 세 포에 처리하여 $37^{\circ} \mathrm{C}, 5 \% \mathrm{CO}_{2}$ 배양기에서 24 시간 동안 배양 한 후 $5 \mathrm{mg} / \mathrm{ml}$ 의 MTT 3-(4,5-dimethyl-2-thiazolyl)-2,5-diphenyl-2H-tetrazolium bromide (MTT; Sigma Co., USA) solution $20 \mu 1$ 를 각 well에 첨가하고 4시간 동안 다시 배양 시킨 후, well 바닥에 형성된 푸른색의 MTT formazan이 생 성되면 상등액을 제거하고 dimethyl sulfoxide (Sigma Co., USA)와 ethanol을 1:1로 혼합한 용액 $200 \mu \mathrm{l}$ 을 첨가하여 천 천히 녹인 후 ELISA plate reader (Synergy2, BioTek, USA) 를 이용하여 $570 \mathrm{~nm}$ 에서 흡광도를 측정하고 $620 \mathrm{~nm}$ 의 ref- 
erence 흡광도를 보정하였다.

\section{신혈관형성 억제 활성 측정}

C57/BL6 마우스에 배양된 B16BL6 melanoma cell line을 50,000 cells $/ 50 \mu 1 /$ head로 피하 이식하였다. 3 일 간격으로 대 조군(vehicle)과 양성 대조군에는 생리 식염수를 투여하고, 실 험군에는 Gomisin A를 $10 \mu \mathrm{g} / \mathrm{head}$ 와 $100 \mu \mathrm{g} / \mathrm{head}$ 로 $100 \mu \mathrm{l}$ 씩 정맥투여 하였다. 암 세포 이식 14일 후 부검하여 암 조직을 포함하는 마우스의 표피 조직을 적출하여 암 조직에 의해 유 도된 신생 혈관의 수를 측정하여, Gomisin A의 신혈관형성 억제 활성을 확인하였다.

\section{폐전이 억제 활성 측정}

C57/BL6 마우스에 배양된 B16BL6 melanoma cell line을 마우스의 꼬리 정맥에 50,000 cells $/ 50 \mu \mathrm{l} / \mathrm{head}$ 주입한 후, 3일 (3회) 간격으로 대조군과 양성 대조군에는 생리 식염수 투여하 였고, 실험군에는 Gomisin A를 $10 \mu \mathrm{g} / \mathrm{head}$ 와 $100 \mu \mathrm{g} / \mathrm{head}$ 로 정맥 주사를 통해 투여 하였다. 암 세포 주입 14 일 후, 종양의 표적기관인 폐를 적출하여 bouin's solution (Sigma Chemical Co., USA)으로 전이된 종양을 고정시킨 후 전이된 종양 colony 수를 측정함으로써 Gomisin $\mathrm{A}$ 의 암 세포 전이 억제 활성 을 확인하였다.

\section{종양세포 부착 억제 활성 측정}

암 세포의 전이 시, 암세포와 세포외기질간에 부착하는 과 정은 중요하며, B16BL6 melanoma cell line과 bovine serum albumin (BSA, control protein), gelatin, collagen, Matrigel, 3 종류의 matrix protein을 사용하여 암세포의 부착능 확인 실 험하였다. 96 well plate에 gelatin, type I collagen, Matrigel, BSA를 각각 코팅한 후, B16BL6 melanoma cell line을 20,000 cells $/ \mathrm{ml}$ 로 분주하였다. Gomisin A를 농도별로 $(0,0.01,0.1$, $1,10,100 \mu \mathrm{g} / \mathrm{ml}$ ) 처리하고, 4시간 동안 배양한 후, PBS로 3회 세척하여 부착하지 않는 세포를 제거하고, XTT solution을 20 $\mu \mathrm{l} / \mathrm{well}$ 로 처리한 후 $590 \mathrm{~nm}$ 에서 흡광도를 측정하였다.

\section{통계처리}

실험결과의 통계학적 처리는 Student's t-tests를 사용하였 으며, $p<0.05$ 수준 이하에서 유의성을 결정하였다.

\section{결과 및 고찰}

\section{Gomisin A의 종양 성장 억제 활성 효과}

항암화학요법제를 개발하기 위한 지금까지의 많은 연구에 서 in vitro에서 활성을 나타내는 물질이 in vivo 적용 시 활성의 감소 또는 소멸되는 현상이 보고되어 왔다. 본 연구에서는 Gomisin A의 항종양 활성의 관찰을 in vivo에서 확인 후, in vitro에서 관련된 mechanism을 규명하고자 하였다. B16BL6 mouse melanoma cell line을 C57/BL6 마우스에 피하주사 (subcutaneous injection)한 후, 미정맥(intravenous injection) 을 통해 Gomisin $\mathrm{A}$ 를 처리하여 in vivo 종양성장에 미치는 영향을 확인하였다(Fig. 1). C57/BL6 마우스에 B16BL6 mela-

\section{A}

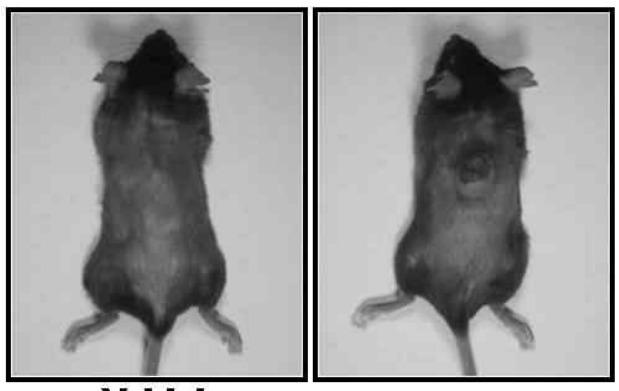

Vehicle

Positive Control

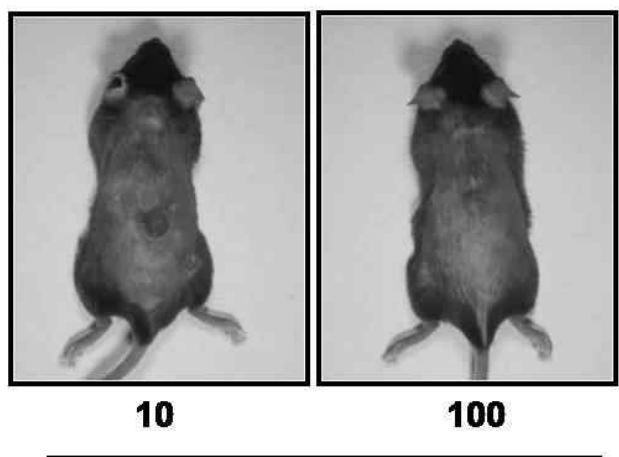

Gomisin A ( $\mu \mathrm{g} / \mathrm{head})$

B

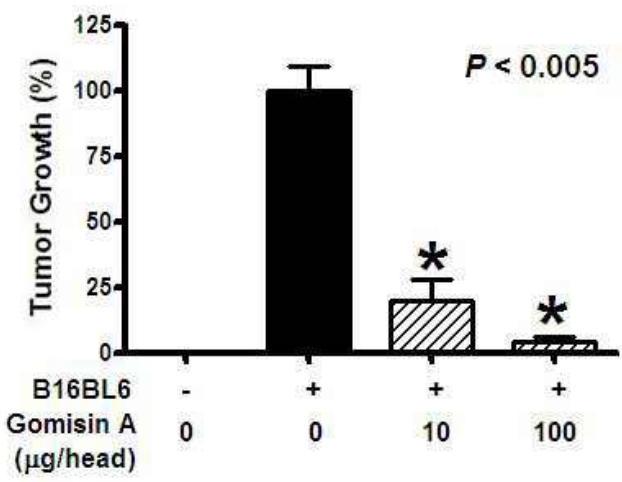

Fig. 1. Growth inhibition of B16BL6 tumor xenograft in C57BL6 mice by administration of Gomisin A. C57BL6 syngeneic mice were subcutaneously implanted with 50,000 B16BL6 melanoma cells per mouse and systemically treated by intravenous injection of Gomisin A (10 and $100 \mu \mathrm{g} /$ head). (A) Photos of the lesions from B16BL6 xenografts after treatment with or without Gomisin A for 2 weeks. (B) Quantitative anaylysis of tumor weight from B16BL6 xenograft in both control and Gomisin A-treated groups. The results are presented as mean \pm S.E. $(\mathrm{n}=5)$. ${ }^{*} p<0.005$, difference vs. Positive control. 


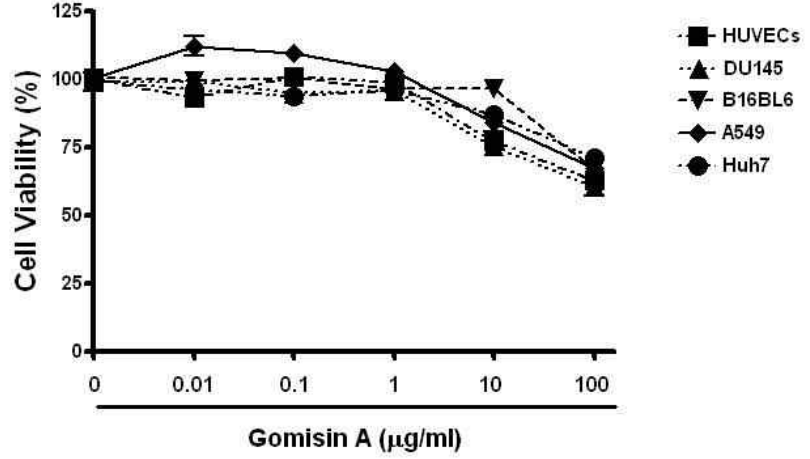

Fig. 2. Cytotoxic effect of Gomisin A on normal cells and a variety of tumor cell lines. HUVECs and Du145, B16BL6, A549, Huh7 cell lines (5,000 cells/well) were seeded into 96 well microtiter plates. Serial diluted Gomisin A added into the plate and the cells were incubated for $24 \mathrm{hr}$. The cell viability was measured by colorimetric assay as described in Materials and Methods.

noma cell line을 주입하지 않은 대조군(vehicle)에서는 종양조 직의 성장이 관찰되지 않았으며, B16BL6 melanoma cell line 만을 주입한 양성 대조군은 vehicle과 비교하여 유의하게 종양 조직의 성장이 확인되었다(Fig. 1A and B). B16BL6 melanoma cell line을 주입하고, 미정맥을 통해 Gomisin A를 $10 \mu \mathrm{g} / \mathrm{ml}$ 과

A

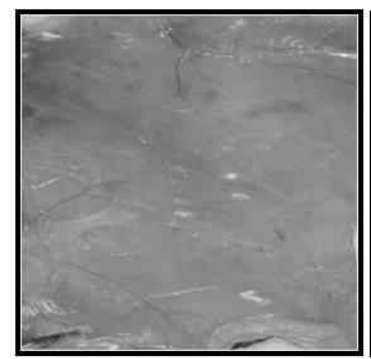

Vehicle

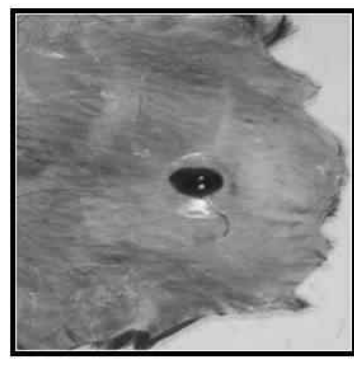

10

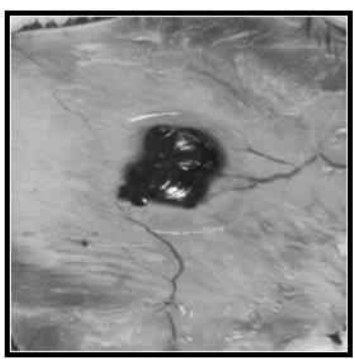

Positive Control

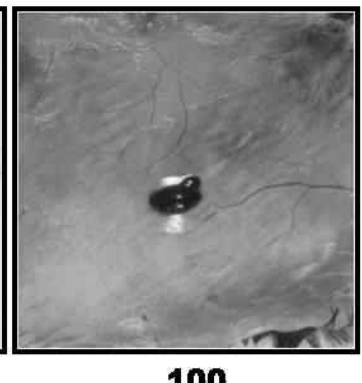

100
$100 \mu \mathrm{g} / \mathrm{ml}$ 의 농도로 처리 하였을 때 각각 $80.5 \pm 8.1 \%$ 와 $96.2 \pm 2 \%$ 의 종양조직의 성장 억제 활성을 나타내었다(Fig. $1 \mathrm{~A}$ and B). 오미자의 lignan 성분 중 하나인 Gomisin A가 in vivo 에서 유의한 종양성장 억제활성을 나타내고 있으나, Gomisin $\mathrm{A}$ 에 의한 종양성장 억제 활성이 어떠한 기전에 의해 나타나는 지 규명할 필요성이 있다. 따라서 Gomisin A에 의한 종양성장 억제활성이 암 세포에 대한 직접적인 독성에 의한 것인지 또 는 다른 억제 기전이 있는지를 확인하고자 하였다.

\section{Gomisin $A$ 의 세포 및 세포주의 생존율에 미치는 영향}

현재 사용되고 있는 대부분의 항암화학요법제는 종양세포 에 대해 apoptosis의 유도 및 cell cycle arrest 등을 통해 직접적 인 살상효과를 나타낸다. 그러나 이러한 활성을 보이는 항암 화학요법제들은 정상세포에 대한 독성이 같이 나타나고 있어 심각한 부작용의 원인이 되고 있다[1,10,19]. Gomisin A의 정 상세포(HUVECs) 및 종양 세포주(A549, B16BL6, Du145, $\mathrm{Huh7}$ )에 대한 직접적인 세포독성 효과를 확인하기 위해, Gomisin A를 농도별 $(0,0.01,0.1,1,10,100 \mu \mathrm{g} / \mathrm{ml})$ 로 처리하 여 24시간 동안 배양한 후 MTT assay를 실시하였다. Gomisin $\mathrm{A}$ 는 정상세포(HUVECs) 및 종양 세포주(A549, B16BL6, $\mathrm{Du} 145, \mathrm{Huh} 7)$ 에서 농도 의존적으로 세포 생존율이 감소하는 현상이 관찰되었다(Fig. 2). 그러나 Gomisin A 0.01 1 $\mu \mathrm{g} / \mathrm{ml}$

B

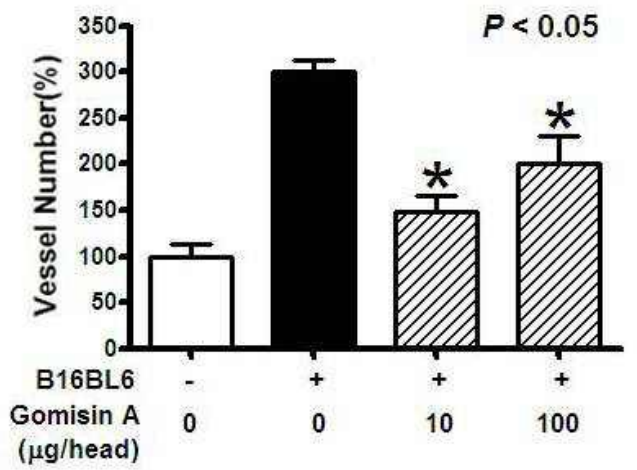

Fig. 3. Effect of Gomisin A on in vivo tumor-induced neovascularization. The ability of Gomisin A to inhibit in vivo tumor-induced angiogenesis was examined by implantation of the B16BL6 cells (50,000 cells/animal) hypodermically intradermally on the shaven dorsum of animals. After 2-week intravenous treatment with Gomisin A (10 and $100 \mu \mathrm{g} / \mathrm{head})$, the mice were sacrificed and skins were excised and fixed in phosphate-buffered $10 \%$ formaldehyde. Capillary at skin interior were counted by two observers in a blinded fashion. (A) Photos of the capillary with the skin interior; (B) Quantitative analysis of capillary number in mice treated with Gomisin A. The results are presented as mean \pm S.E $(\mathrm{n}=5) .{ }^{*} p<0.05$, difference vs. Positive control. 
의 농도 범위에서는 정상세포 및 종양 세포주에서 유의한 독 성이 관찰되지 않았으며, $10 \mu \mathrm{g} / \mathrm{ml}$ 에서 $75 \%$ 이상의 생존율을 나타내어 직접적인 살상효과는 관찰되지 않았다(Fig. 2). 따라 서, Gomisin A의 항종양 활성은 종양세포에 대한 직접적인 독성을 나타내는 것이 아니라, 혈관신생 및 다른 경로의 억제 와 활성화를 통해 유도될 수 있음을 암시하여 주고 있다. 또한 종양 면역활성, 암세포 자살 유도능과 같은 다양한 부분의 연 구가 수반되어야 할 것이다.

\section{종양 조직에 의해 유도되는 신혈관형성 저해 효과}

암조직과 같이 세포증식이 왕성한 경우, 공간적으로 세포의 수가 증가되어 혈관에 의해 산소가 확산될 수 있는 거리는 $150 \mu \mathrm{m}$ 에 불과한것으로 알려져 있으며[5], 암 조직 내부의 세 포에 산소와 영양분이 전달되기 위해서는 반드시 신혈관형성 이 유도되어야 한다. 특히 암세포는 새롭게 형성되는 혈관을 통해 급속한 성장과 다른 조직으로의 전이를 하게 된다. Gomisin A는 in vivo에서 강력한 항종양 활성을 나타내었으나
(Fig. 1) 정상세포 및 종양세포주에 대한 직접적인 독성효과는 나타내지 않았다(Fig. 2). 따라서 Gomisin A의 항종양 활성이 신혈관형성 억제활성에 의한 것인지 규명하고자 하였다. Gomisin A의 신혈관형성 억제 효과는 B16BL6 melanoma cell line을 C57/BL6 마우스의 피하에 주입하여 종양조직을 형성 하고, Gomisin A를 미정맥으로 투여하여 종양조직 주변으로 형성되는 신생혈관의 수를 비교하여 확인하였다. B16BL6 melanoma cell line을 주입한 양성 대조군에서 종양세포를 주 입하지 않은 대조군(vehicle)에 비해 종양조직 주변으로 $300 \pm 12.8 \%$ 새로운 혈관의 형성이 관찰되었다(Fig. $3 \mathrm{~A}$ and B). Gomisin A $(10,100 \mu \mathrm{g} / \mathrm{ml})$ 를 처리한 실험군에서는 양성 대조 군에 비해 종양조직 주변의 신생혈관의 수가 각각 $151 \pm 16.9 \%$, $98.5 \pm 29.5 \%$ 의 유의한 감소율을 나타내었다(Fig. $3 \mathrm{~A}$ and B). 이러한 결과는 Gomisin A가 종양세포에 의해 유도되는 신혈 관형성을 억제함으로서 항종양 활성을 나타내고 있다. 또한, 신혈관형성의 억제를 통한 종양조직의 성장억제는 인체 내 정상조직에 대한 독성을 유발하지 않음으로서 종양조직에 대

\section{A}

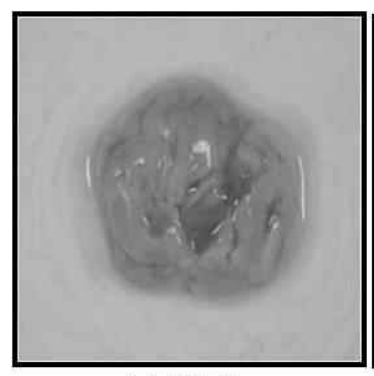

Vehicle

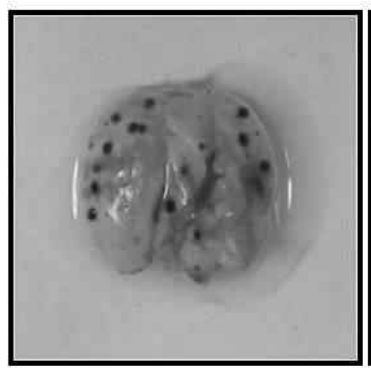

10

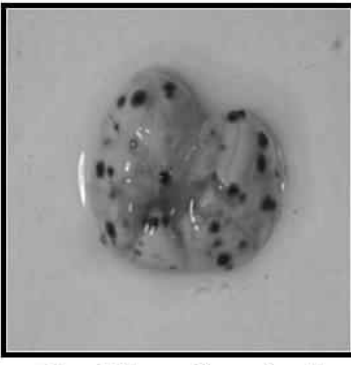

Positive Control

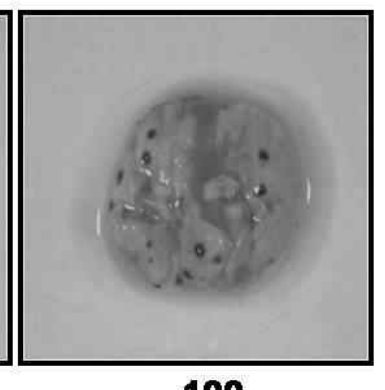

100

\section{Gomisin A ( $\mu$ g/head)}

B
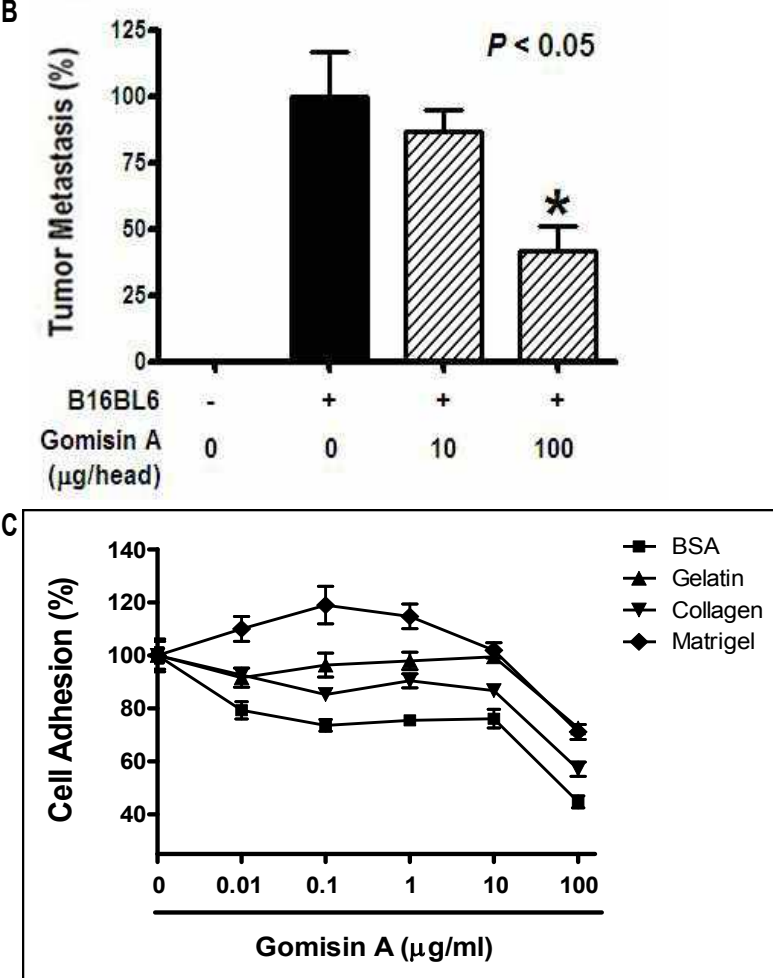

Fig. 4. Effect of Gomisin A on in vivo pulmonary metastasis of melanoma cells and adhesion of tumor cell to extracellular matrix proteins. B16BL6 cells were injected into the lateral tail vein of 6-week-old male C57BL/6 mice. After 2-week intravenous treatment with Gomisin A (10 and $100 \mu \mathrm{g} / \mathrm{head}$ ), the mice were sacrificed and lungs were excised and fixed in phosphate-buffered $10 \%$ formaldehyde. Metastatic nodules at lung surfaces were counted by two observers in a blinded fashion. (A) Photos of the lung with the metastatic nodules; (B) Statistical metastatic nodules in lung of mice in different treatment groups. Results were presented as mean \pm S.E. $(n=5)$. (C) Effect of Gomisin A on the adhesion of B16BL6 cell line to immobilized extracellular matrix proteins. B16BL6 cell line with various concentration of Gomisin A was added to the BSA, Gelatin, type I collagen and Matrigel coated 96-well plates. After incubation, the adhesion B16BL6 cell line was determined. ${ }^{*} p<0.05$, difference vs. Positive control. 
한 특이적 억제활성이 있음을 시사하여 주고 있다.

종양 세포의 폐 전이 및 세포외기질과의 부착 억제 활성 효과 암세포가 정상세포와 구분되는 또 다른 특징은 발생한 원래 위치에서 벗어나 다른 장기에서 증식하는 현상이다. 암세포의 전이는 암 치료 실패의 가장 큰 원인을 제공하며, 환자를 사망 에 이르게 하는데 결정적인 역할을 한다. 따라서 Gomisin A의 종양 전이억제활성은 C57/BL6 마우스에 B16BL6 melanoma cell line을 미정맥 주사(intravenous injection)를 통해 주입하 고 Gomisin $\mathrm{A}$ 를 농도별로 처리한 후 폐를 적출하여 cancer colony의 수를 측정하여 확인하였다(Fig. 4). B16BL6 melanoma cell line을 단독 주입한 양성 대조군은 암 세포주를 주입하 지 않은 대조군(vehicle)에 비해 유의한 cancer colony가 확인 되었다(Fig. 4A). B16BL6 melanoma cell line의 전이를 유도하 고 Gomisin A를 $10 \mu \mathrm{g} / \mathrm{head}$ 로 처리한 그룹에서 $13.5 \pm 8.56 \%$, $100 \mu \mathrm{g} / \mathrm{head}$ 에서 $58.3 \pm 9.12 \%$ 의 통계적으로 유의한 종양세포 전이억제활성을 나타내었다(Fig. $4 \mathrm{~A}$ and B).

종양 세포의 전이과정에서 원발 부위의 조직에서 세포 접착 능이 감소해 조직으로부터 떨어져 나온 후, 전이 부위의 기저 막 세포외기질(extracellular matrix)에 부착하여 이동하는 단 계는 필수적인 단계이다. Gomisin A에 의한 종양전이 억제활 성의 기전을 확인하기 위해, 종양세포주와 기저막 세포외기질 의 부착에 미치는 영향을 확인하였다. 종양세포와 세포외기질 과의 부착에 미치는 영향은 BSA (control protein), Gelatin, Collagen, Matrigel이 coating 된 plate에 B16BL6 melanoma cell line이 부착하는 수를 비교하여 확인하였다. B16BL6 melanoma cell line의 부착은 BSA가 coating된 control과 Gelatin, Collagen, Matrigel의 세포외기질이 coating된 시험군에서 Gomisin A의 농도 0.01 10 $\mathrm{\mu g} / \mathrm{ml}$ 의 범위 까지는 유의한 부착 억제활성이 관찰되지 않았다(Fig 4C). Gomisin A $100 \mu \mathrm{g} / \mathrm{ml}$ 에서 B16BL6 melanoma cell line의 부착능은 BSA (55.35 $2.27 \%)$, Gelatin (27.37 $\pm 1.58 \%)$, Collagen (42.96 $\pm 2.67 \%)$, Matrigel $(28.91 \pm 2.84 \%)$ 까지 각각 억제됨을 확인할 수 있었다 (Fig. 4C). 지금까지의 결과는 Gomisin A가 나타내는 종양세 포의 전이 억제활성은 세포외기질 분자에 대한 종양세포의 결합과정을 억제함으로서 나타날 수 있는 현상임을 시사하여 주고 있다. 또한 세포외기질 성분 중 collagen분자에 대한 부착 억제활성이 매우 높게 관찰되었고, 대부분의 세포외기질 성분 이 포함된 Matrigel에 대한 부착 역시 유의하게 억제되었다. 따라서 Gomisin A의 종양세포와 세포외기질간의 부착 저해 활성은 향후 암전이 억제제로서 유용하게 사용될 수 있음을 나타내는 주요한 자료로 판단된다.

\section{감사의 글}

이 논문은 2009년도 호서대학교 재원으로 학술연구비 지원
을 받아 수행되었으며, 이에 감사 드립니다(2009-0158).

\section{References}

1. Barisic, K., Petrik, J. and Rumora, L. 2003. Biochemistry of apoptotic cell death. Acta Pharm 53, 151-164.

2. Cho, Y. J., Ju, I. S., Kim, B. C., Lee, W. S., Kim, M. J., Lee, B. G., An, B. J., Kim, J. H. and Kwon, O. J. 2007. Biological activity of omija (schizandra chinensis baillon) extracts. $J$. Kor. Soc. Appl. Bio. Chem 50, 198-203.

3. Chon, S. U., Bae, C. H. and Lee, S. C. 2012. Antioxidant and cytotoxic potentials of methanol extracts from taraxacum officinale F. H. Wigg. at different plant parts. Kor. J. Plant Res. 25, 232-239.

4. Cuvelier, M. E., Richard, H. and Berset, C. 1996. Antioxidative activity and phenolic composition of pilot-plant and commercial extracts of sage and rosemary. J. Am Oil. Chem Soc. 3, 645-652.

5. Dang, C. V. and Semenza, G. L. 1999. Oncogenic alterations of metabolism. Trends Biochem Sci. 24, 68-72.

6. Folkman, J. 1995. Angiogenesis in cancer, vascular, rheumatoid and other disease. Nat. Med 1, 27-31.

7. Folkman, J. 1992. The role of angiogenesis in tumor growth. Semin. Cancer Biol. 3, 387-400.

8. Folkman, J. and Klagsbrun, M. 1987. Agiogenic factors. Science 235, 442-447.

9. Folkman, J. and Cotra, R. 1976. Relation of vascular proliferation to tumor growth. Int. Rev. Exp. Path. 16, 207-248.

10. Frankfurt, O. S. and Krishan, A. 2003. Apoptosis-based drug screening and detection of selective toxicity to cancer cell. Anticancer Drugs 14, 555-561.

11. Herramnn, K. 1975. Flavonols and flavones in food plants: a review. Int. J. Food Sci. Technol. 11, 433-448.

12. Jeon, T. W., Jo, C. H., Kim, H. and Byun, M. W. 2002. Inhibitory effect on tyrosinase and xanthine oxidase, and nitrite scavenging activities of schizandrae fructus extract by gamma irradiation. Kor. J. Food Pre. 9, 369-374.

13. Jeong, M. H., Kim S. S., Ha, J. H., Jin, L., Lee, H. J., Kang, H. Y., Park, S. J. and Lee, H. Y. 2009. Enhancement of anticancer activity of acer mono by high pressure extraction process. J. Kor. Soc. Food Sci. Nutr. 38, 1243-1252.

14. Kamphaus, G. D., Colorado, P. C., Panka, D. J., Hopfer, H., Ramchandran, R., Torre, A., Maeshima, Y., Mier, J. W., Sukhatme, V. P. and Kalluri, R. 2000. Canstatin, a novel matrix-derived inhibitor of angiogenesis and tumor growth. J. Biol. Chem 275, 1209-1215.

15. Kang, T. B. and Liang, N. C. 1997. Studies on the inhibitory effects of quercetin on the growth of HL-60 leukemia cells. Biochem Pharmacol. 54, 1013-1018.

16. Kim, C. H., Kwon, M. C., Kim, H. S., Ahn, J. H., Chio, G. P., Choi, Y. B., Ko, J. R. and Lee, H. Y. 2007. Enhancement of Immune Activities of Kadsura Japonica Dunal. through Conventional Fermentation Process. Kor. J. Med Crop Sci. 15, 162-169.

17. Kim, J. S., Park, B. Y., Park, E. K., Lee, H. S., Hahm, J. C., Bae, K. H. and Kim, M. Y. 2006. Screening of anti-angiogenic activity from plant extracts. Kor. J. Pharmacogn. 37, 253-257. 
18. Kim, K. S., Kang, S. S. and Ryu, S. N. 2002. Quantitative analysis liganans from fruits of schizandra chinensis. Kor. J. Pharmacogn. 4, 272-276.

19. Lowe, S. W. and Lin, A. W. 2000. Apoptosis in cancer. Carcinogenesis 21, 485-495.

20. O'Reilly, M. S, Boehm, T., Shing, Y., Fukai, N., Vasios, G., Lane, W. S., Flynn, E., Birkhead, J. R., Olsen, B. R. and Folkman, J. 1997. Endostatin: an endogenous inhibitor of angiogenesis and tumor growth. Cell 88, 277-285.

21. Park, K. Y., Moon, S. H., Rhee, S. H., Baek, K. Y. and Lim, S. Y. 1955. Effect of tannin from persimmon leaves on the growth inhibition and the synthesis of mRNA of type IV collagen in AZ-521 human gastric cancer cells. Environ. Muta. Carcino. 15, 32-37.
22. Rho, S. N. and Oh, H. S. 2002. Effect of Omija (Schizandra Chinensis Baillon) extracts on the growth of liver cancer cell line SNU-398. Kor. J. Nutr. 35, 201-206.

23. Sharman, S., Stutzman, D. S., Kelloff, G. J. and Steele, V. E. 1994. Screening of potential chemopreventive agents using biochemical markers of carcinogenesis. Cancer Res. 54, 5848-5855.

24. Shin, S. R., Hong, J. Y., Nam, H. S., Yoon, K. Y. and Kim, K. S. 2006. Antioxidative effects of extracts of Korean herbal materials. J. Kor. Soc. Food Sci Nutr. 2, 187-191.

25. Zou, Z., Anisowicz, A., Hendrix, M. J., Thor, A., Neveu, M., Sheng, S., Rafidi, K., Seftor, E. and Sager, R. 1994. Maspin, a serpin with tumor-suppressing activity in human mammary epithelial cells. Science 263, 526-529.

\section{초록 : Gomisin A의 신혈관형성 저해를 통한 종양 성장 및 전이 억제 효과}

김도윤 ${ }^{1}$ 유호진 ${ }^{1}$ · 윤미소 ${ }^{1}$ 박주훈 ${ }^{1}$ · 장상희 ${ }^{2} \cdot$ 이환명 ${ }^{1}$

( ${ }^{1}$ 호서대학교 화장품과학과, ${ }^{2}$ 구미대학교 웰빙식품과)

항암화학요법제는 의약품 시장 중 가장 큰 시장의 하나이며, 세계적으로 수많은 연구와 신약의 개발이 진행되고 있다. 그러나 암 세포 뿐만 아니라 정상세포와 조직에 대한 독성과 내성으로 인해 심각한 부작용이 지속되어, 최근 신혈관형성 억제와 천연물 유래의 암 치료제 개발이 많은 관심을 얻고 있다. 본 연구에서는 오미자의 활성 성분 중 하나인 Gomisin A의 종양성장 및 전이억제 효과와 이들의 작용기전에 대해 확인하고자 하였다. Gomisin A의 종양성장 억제활성은 B16BL6 cell line을 C57/BL6 mice의 피하에 주입하여 유도된 종양모델을 활용 하였으며, Gomisin A $10 \mu \mathrm{g} / \mathrm{ml}, 100 \mu \mathrm{g} / \mathrm{ml}$ 에서 양성 대조군에 비해 각각 80.5 $\pm 8.1 \%, 96.2 \pm 2 \%$ 의 유의한 억제활성을 나타내었 다. Gomisin A의 암세포에 대한 직접적인 독성은 MTT assay를 통해 확인하였고, 정상세포(HUVECs)와 종양세포주 (A549, B16BL6, Du145, Huh7)에 대한 유의한 독성은 관찰되지 않았다. 종양조직에 의해 유도되는 신혈관형성 억제능은 C57/BL6 mice에 배양된 B16BL6 cell line을 피하주사하여 종양조직을 형성하고, 이들이 유도하는 신생혈 관에 대한 Gomsin A의 억제활성을 확인하였다. Gomisin A를 $10 \mathrm{\mu g} / \mathrm{head}$ 와 $100 \mathrm{\mu g} / \mathrm{head}$ 에서 신혈관형성 억제 활성은 양성 대조군에 비해 각각 $151 \pm 16.9 \%, 98.5 \pm 29.5 \%$ 의 유의한 감소활성을 나타내었다. 종양전이 억제활성은 B16BL6 cell line을 C57/BL6 mice 미정맥에 주입하여 in vivo 폐전이 모델을 만들고 폐에 전이된 종양의 colony를 측정하여 확인하였다. Gomisin A의 농도 $10 \mu \mathrm{g} / \mathrm{head}, 100 \mu \mathrm{g} / \mathrm{head}$ 에서 각각 양성 대조군에 비해 $13.5 \pm 8.56 \%$, $58.3 \pm 9.12 \%$ 의 전이 억제활성을 나타내었다. 또한 Gomisin A는 B16BL6 cell line이 세포외기질에 대한 부착능을 유의하게 감소시킴을 확인하였다. 이러한 결과는 Gomisin A의 종양성장 억제활성이 암세포에 대한 직접적인 독성 에 의한 것이 아닌 신혈관형성 억제에 의한 것이며, 또한 종양 전이 억제 활성을 나타냄으로서 향후, 암 예방 및 치료제 개발의 선도물질을 제공할 수 있음을 확인하였다. 본 연구는 오미자의 주요 생리활성 물질인 Gomisin $\mathrm{A}$ 의 종양성장 억제 활성과 전이억제 활성을 규명하고자 하였다. Gomisin A가 종양성장 억제활성이 있음을 확인하 였고, 이러한 효과는 종양세포에 대한 직접적인 독성에 의한 것이 아니라, 종양조직에 의해 유도되는 신혈관형성 저해 활성에 의해 나타나는 것을 규명하였다. 이러한 결과는 대부분의 항암화학요법제가 가지는 독성작용을 극복하 고, 선택적인 종양성장 억제제로서의 개발 가능성을 시사하여 주고 있다. 또한 Gomisin A는 종양세포의 세포외기질 부착억제활성을 통해 암 전이 억제활성을 나타냄을 확인하였다. 지금까지의 결과는, Gomisin A를 활용한 부작용이 적으며 효과적인 암 치료제 개발의 선도 물질로서 활용 가능성을 나타내 주고 있으며, 또한 고 기능성 식품 및 화장품의 개발에 활용이 가능할 것이다. 그러나, 향후 종양 면역활성, 암세포 자살 유도능과 같은 다양한 부분의 연구가 수반되어야 할 것이다. 